India in the Chinese Imagination 


\section{ENCOUNTERS WITH ASIA}

\section{Victor H. Mair, Series Editor}

Encounters with Asia is an interdisciplinary series dedicated to the exploration of all the major regions and cultures of this vast continent. Its time frame extends from the prehistoric to the contemporary; its geographic scope ranges from the Urals and the Caucasus to the Pacific. A particular focus of the series is the Silk Road in all of its ramifications: religion, art, music, medicine, science, trade, and so forth. Among the disciplines represented in this series are history, archeology, anthropology, ethnography, and linguistics. The series aims particularly to clarify the complex interrelationships among various peoples within Asia, and also with societies beyond Asia.

A complete list of books in the series is available from the publisher 


\title{
INDIA IN THE
}

\section{CHINESE IMAGINATION}

MYTH, RELIGION, AND THOUGHT

\author{
EDITED BY \\ JOHN KIESCHNICK AND MEIR SHAHAR
}

\section{$\overline{\text { PENN }}$}

UNIVERSITY OF PENNSYLVANIA PRESS

PHILADELPHIA 
Copyright (C) 2014 University of Pennsylvania Press

All rights reserved. Except for brief quotations used for purposes of review or scholarly citation, none of this book may be reproduced in any form by any means without written permission from the publisher.

\author{
Published by \\ University of Pennsylvania Press \\ Philadelphia, Pennsylvania 19104-4112 \\ www.upenn.edu/pennpress \\ Printed in the United States of America \\ on acid-free paper \\ 109876654321
}

Library of Congress Cataloging-in-Publication Data

India in the Chinese imagination / edited by John Kieschnick and Meir Shahar. - 1st ed.

p. cm. - (Encounters with Asia)

Includes bibliographical references and index.

ISBN 978-0-8122-4560-8 (hardcover : alk. paper)

1. China-Civilization-Indic influences. 2. China-

Relations-India. 3. India-Relations-China. I. Kieschnick, John, 1964- I. Shahar. Meir, 1959- III. Series: Encounters with Asia.

DS721.I59 2014

303.48'251054-dc23

2013022777 
In Memory of

John R. McRae 
This page intentionally left blank 